https://doi.org/10.31470/2706-7904-2020-15-272-276

\title{
КОМУНІКАТИВНА КОМПЕТЕНТНІСТЬ МАЙБУТНІХ ПСИХОЛОГІВ ЯК ПСИХОЛІНГВІСТИЧНА ПРОБЛЕМА
}

\section{Communicative Competence of Future Psychologists as a Psycholinguistic Problem}

\author{
Liudmyla Khametova \\ Senior Lecturer \\ Pereiaslav-Khmelnytskyi Hryhorii Skovoroda State Pedagogical University (Ukraine) \\ 1_xametova@ukr.net \\ https://orcid.org/0000-0001-9695-9619
}

\begin{abstract}
Modern education is focused on formation of the basic and professional competences in applicants of higher education with a view to successful implementation of youth in future professional activities and harmonious development of personality. Competence includes a set of basic knowledge, skills, and abilities, humanitarian values that help people to find their place in the professional world and realized themselves in accordance with their skills.
\end{abstract}

Key words: competency, competence, communicative competence, communicative skills.

\section{Вступ \\ Introduction}

Глобалізаційні виклики сучасності та внутрішні соціально-політичні умови розвитку суспільства вимагають якісно нового наповнення освітнього процесу. Нова якість вищої освіти - це не лише модернізація у змістовному наповненні освітніх програм з урахуванням формування базових та професійних компетентностей у здобувачів вищої освіти, а й удосконалення якості викладання та нові підходи до навчання. Як зазначено у статті 1 першого розділу Закону України «Про освіту», що «компетентність - здатність особи успішно соціалізуватися, навчатися, провадити професійну діяльність, яка виникає на основі динамічної комбінації знань, умінь, навичок, способів мислення, поглядів, цінностей, інших особистих якостей» (Закон України, 2020). Найважливішим у освітньому процесі майбутніх психологів постає питання формування базових та професійних компетенцій, які пов'язані, передусім 3 професійним мовленням. Саме тому на розвитку їхніх комунікативних навичок зосереджується особлива увага в освітньому процесі ЗВО. Вирішення цього завдання лежить у площині психолінгвістики. 


\section{Методи та методики дослідження}

Methods and Techniques of the Research

У дослідженні використовувалися теоретичні методи дослідження, які були зорієнтовані на виконання аналізу, узагальнення і опис різних визначень поняття «комунікативна компетентність» - базової компетентності, необхідної для успішної соціалізації майбутнього психолога як фахівця.

\section{Результати \\ Results}

Загальновідомо, що комунікація передбачає взаємодію людей у процесі спільної життєдіяльності, що включає обмін інформацією у різноманітних процесах спілкування за допомогою мовних знаків i немовних засобів. А комунікативна компетенція вимірюється ефективністю здатності включатися у ці процеси та умінням спілкуватися 3 людьми як в межах своєї професії, так і в межах інших професій. Комунікативна компетенція уперше набула статусу предмету наукового дослідження ще 1972 році, коли Д. Хаймз зосередив увагу на сукупності знань мовця для забезпечення компетентності у спілкуванні. Мовленнєву комунікацію він представив через мовленнєву ситуацію, мовленнєву подію і мовленнєвий акт, на відміну від Н. Хомського, який наголошував на пріоритеті правильності граматичних конструкцій (Хаймс, 1975).

Психолінгвістичний підхід до освітнього процесу у вищій школі дає змогу обгрунтувати зміст теоретичного та практичного навчання та визначити комплексні комунікативні компетенції, які б враховували пізнавальні здібності студентів, були орієнтовані на особистісну активність, пошук, творчість і разом 3 тим відповідали викликам соціальних реалій. Як слушно зазначає Л. Калмикова, компетентність, зокрема комунікативна, з огляду на освітні завдання ЗВО є «кінцевою метою їх діяльності з підготовки фахівців», «освітнім ефектом, який досягається комплексом засобів навчання і виховання у виші, якісною характеристикою випускників вищої школи, критерієм іiі результативності» (Калмикова, 2008).

Ю. Рашкевич у рамках проекту TUNING (Налаштування освітянських структур в Європі) виділяє компетентності загальні та спеціальні (фахові).

Загальні (generic) компетентності - знання, розуміння, навички та здатності, якими студент оволодіває у рамках виконання певної програми навчання, але які мають універсальний характер.

До спеціальних (subject related) відносяться компетентності, які: 
- с специфічними для даної предметної області (галузі/напряму дисципліни);

- безпосередньо пов’язані із спеціальними знаннями у предметній області;

- визначають профіль програми, тобто роблять ії індивідуальною, істотно відмінною від інших програм (Рашкевич, 2015).

Феномени «компетенція» i «компетентність» тлумачаться у вищій психологічній освіті по-різному. Л. Калмикова розмежовує ці поняття. Компетенція, на iï думку, - це базова величина, вихідна субстанція, якісна характеристика фахівця, як відповідного за своїми знаннями, уміннями і навичками вимогам суспільства, галузі, виробництва тощо, то компетентність - вивідна його характеристика, що трансформувалася у вторинну якість і стала внутрішньою, невід’ємною стороною особистості професіонала, сталим якісним станом його фахової активності, професійним надбанням суб'єкта діяльності, його вищою потребою» (Калмикова, 2016).

Дослідницею також обгрунтована необхідність визначення місця психолінгвістики в структурі державних стандартів освіти у ЗВО України згідно 3 комунікативно-компетентнісний підходом та визначина роль психолінгвістики у формуванні загальних та спеціальних компетентностей, які визначені в матеріалах європейського освітнього співтовариства як обов'язкові для якісного, повноцінного становлення фахівців з вищою освітою (Калмикова, 2008).

У схожому векторі працює науковець М. Галицька, яка розглядає компетентнісний підхід як новий концептуальний орієнтир навчальних закладів та чинник модернізації змісту освіти. Порівнюючи зміст понять «компетентність» та «компетенція», вона визначає комунікативну компетентність студентів ЗВО як «інтегральну якість особистості, яка синтезує в собі загальну культуру спілкування та iï специфічні прояви в професійній діяльності» (Галицька, 2015: 39).

М. Галицька виділяє наступні складові комунікативної компетентності:

- іншомовна комунікативна компетенція (передбачає знання лексики, граматики, семантики, фонології та уміння використовувати їх у мовленнєвому процесі, що здійснюється у контексті діалогу культур);

- професійна компетенція (володіння професійною термінологією);

- стратегічна компетентність (здатність використовувати вербальні та невербальні комунікативні стратегії для обміну інформацією, компенсувати нерозуміння, незнання мовного коду;

- соціальна компетенцію (інтеракції в ситуаціях соціального спілкування) (Галицька, 2015).

Проаналізувавши наукові джерелавиділяємо наступні компоненти комунікативної компетентності: 
- Володіння граматичними, лексичними, фонетичними конструктами як рідної так і однією іноземною мовою у контексті професійного спрямування.

- Володіння елементарними навиками ораторського мистецтва.

- Культура мовленнєвого спілкування та знання національних особливостей спілкування у межах професії.

- Знання невербальних засобів мовленнєвого спілкування.

- Уміння складати та, відповідно, читати психологічний портрет клієнтів.

- Уміння розуміти психологічні особливості та моральні складові співрозмовників.

- Наявність достатньо розвиненого рівня емпатії для розуміння потреб та інтересів інших людей.

- Уміння працювати в команді та вести переговори.

- Уміння визначати ступінь конфліктності у колективі, передбачати конфліктні ситуації та позитивно їх вирішувати.

- Уміння бути лідером в діаді.

- Здатність до розкриття потенціалу кожного клієнта.

- Уміння дотримуватися правил мовленнєвого етикету.

- Уміти емпатійно слухати;

- Уміння будувати психотерапевтичні й психоконсультаційні дискурси.

Важливими аспектами досягнення взаєморозуміння в комунікації $\epsilon$ налагодження контакту 3 співрозмовником (однією людиною чи групою), забезпечення зворотного зв'язку.

\section{Висновки \\ Conclusions}

Провідне місце у рейтингу компетентностей майбутнього психолога посідає комунікативна компетентність, оскільки інтегрує в собі низку умінь та навичок в єдине ціле.

Володіння майбутніх психологів мовленнєвими конструкціями, знання специфіки їх побудови, фахової термінології, уміння ефективно поєднувати вербальні й невербальні засоби спілкування та тлумачити їх, при цьому враховуючи психологічну складову комунікації, дозволить їм успішно реалізовувати власний професійний мовленнєво-мовний потенціал.

Більшість базових компетентностей майбутніх психологів стосуються знання 
рідної та іноземної мов; умінь спілкуватися з людьми, домовлятися, впливати на них і розуміти їх; умінь працювати в команді; бути як генератором ідей, так і виконавцем; умінь взаємодіяти з людьми і вести переговори, орієнтуватися на клієнта, тобто дій мовленнєво-комунікативно зорієнтовані.

\section{Література}

References

Галицька, М. (2015). Складові комунікативної компетентності студентів вищих навчальних закладів. Освітологічний дискурс, 2(10). http://oaji.net/articles/2016/29231456731608.pdf

Калмикова, Л. (2008). Психолінгвістика у ВНЗ України і Болонський процес: проблеми реалізації європейського змісту освіти і компетентнісного підходу. Рідна школа, 10, 61-63.

Калмикова, Л.О. (2016). Феномени «компетенція» i «компетентність» у психологопедагогічній науці i вищій педагогічній освіті. Початкова школа. http://ephsheir.phdpu.edu.ua

Рашкевич, Ю.М. (2016). Матеріали Наиіональної команди експертів, проекту СС НЕО в Україні. http:/lawfaculty.chnu.edu.ua/wpcontent/uploads/2016/11/Competence_Approach_Rashkevych_Nov 